\title{
The prevalence of antibodies to Toxoplasma gondii in horses in Changji Hui Autonomous Prefecture, Xinjiang, northwestern China
}

\author{
Prevalência de anticorpos contra Toxoplasma gondii em cavalos na Região de Uygur, \\ Xinjiang, Noroeste da China \\ Jin-Lei Wang'; Dong-Hui Zhou ${ }^{1 *}$; Jia Chen'; Guang-Xue Liu' ${ }^{1}$; Wen-Bing Pu²; \\ Ting-Yu Liu' ${ }^{2}$ Si-Yuan Qin ${ }^{1}$; Ming-Yang Yin ${ }^{1}$; Xing-Quan Zhu ${ }^{1}$

\begin{abstract}
${ }^{1}$ State Key Laboratory of Veterinary Etiological Biology, Lanzhou Veterinary Research Institute, Chinese Academy of Agricultural Sciences, Gansu Province, Lanzhou, PR China

${ }^{2}$ Changji Prefecture Animal Disease Control and Prevention Center, Xinjiang Uygur Autonomous Region, PR China
\end{abstract}

Received February 6, 2015

Accepted May 14, 2015

\begin{abstract}
Toxoplasmosis is a worldwide zoonosis caused by Toxoplasma gondii, which can infect warm-blooded animals and humans. The present study was performed to investigate the seroprevalence of T. gondii in horses in Xinjiang, northwestern China. A total of 637 blood samples were collected from seven regions in Changii Hui Autonomous Prefecture, Xinjiang in 2011 and assayed for T. gondii antibodies using the modified agglutination test (MAT). Risk factors (age, gender, and region) related to seroprevalence were determined by a multivariate logistic regression analysis. A total of 200 horses (31.4\%, 95\% CI 27.79-35.00) were seropositive for T. gondii. Age, gender, and region present no association with seroprevalence $(\mathrm{p}>0.05)$ in the logistic regression analysis. The results indicated that $T$. gondii is widely prevalent in horses in Xinjiang, northwestern China, representing a serious threat to animal and human health. Therefore, more careful measures should be performed to control and prevent T. gondii infection in horses from Xinjiang, northwestern China.
\end{abstract}

Keywords: Toxoplasma gondii, horse, seroprevalence, modified agglutination test (MAT), China.

\section{Resumo}

A toxoplasmose é uma zoonose global causada pelo Toxoplasma gondii, o qual pode infectar animais de sangue quente e seres humanos. Este estudo foi realizado com o objetivo de investigar a soroprevalência em cavalos para T. gondii, na regiáo de Xinjiang, no Noroeste da China. Em 2011, foram recolhidas 637 amostras de sangue em sete distritos da Prefeitura Autônoma de Changji Hui do Xinjiang, as quais foram testadas para a presença de anticorpos, utilizando-se o teste de aglutinação modificado (MAT). Foram estimados fatores de risco relacionados com a soroprevalência (idade, sexo e distrito), através de uma análise de regressão logística multivariada. Um total de 200 equinos $(31,4 \%, 95 \%$ IC 27,79 - 35,00) foi positivo para $T$. gondii. Idade, sexo e região estudada não apresentaram associação com a soroprevalência $(\mathrm{p}>0,05)$ na análise de regressão logística. Os resultados revelam que a infecção por $T$. gondii tem uma prevalência generalizada em todo o território de Xinjiang, no Noroeste da China, constituindo uma séria ameaça à saúde de animais e de humanos. Consequentemente, propóe-se que sejam adotadas medidas reforçadas para o controle e prevençáo da infecçáo de cavalos por T. gondii, no Xinjiang, Noroeste da China.

Palavras-chave: Toxoplasma gondii, cavalo, soroprevalência, teste de aglutinação modificado (MAT), China.

\footnotetext{
*Corresponding author: Dong-Hui Zhou. State Key Laboratory of Veterinary Etiological Biology, Lanzhou Veterinary Research Institute, Chinese Academy of Agricultural Sciences, Gansu Province 730046, Lanzhou, PR China.

e-mail: zhoudonghui@caas.cn
} 


\section{Introduction}

Toxoplasma gondii is an important zoonotic intracellular apicomplexan protozoan that can infect humans and nearly all warm-blooded animals worldwide (DUBEY, 2010; MONTOYA \& LIESENFELD, 2004; TENTER et al., 2000; SOUSA et al., 2014; CERRO et al., 2014; BARROS et al., 2014). Humans and animals can be infected mainly through the ingestion of tissue cysts from undercooked or raw meat or through the consumption of food or water contaminated with sporulated oocysts shed by infected felids (KIJLSTRA \& JONGERT, 2008). Around the world, approximately one-third of the human population has been infected with $T$. gondii, and it is estimated that nearly $7.88 \%$ of the population in China has been exposed to T. gondii (DUBEY, 2010; ZHOU et al., 2011). Toxoplasmosis is typically asymptomatic in healthy individuals but can cause mortality and morbidity in congenitally infected and immunocompromised patients, such as individuals with AIDS (MONTOYA \& LIESENFELD, 2004; BELANGER et al., 1999).

Felids are the only recognised definitive hosts of $T$. gondii, but humans and virtually all warm-blooded species, including horses, can be intermediate hosts (ELMORE et al., 2010). Horses are widely distributed in the Xinjiang Uygur Autonomous Region, serving as an important means of transportation for the local population. Humans may acquire T. gondii infections by consuming improperly cooked horse meat containing tissue cysts (POMARES et al., 2011). In horses, T. gondii infection is generally subclinical; however, atypical clinical symptoms, including fever, ataxia, retinal degeneration and encephalomyelitis, sometimes appear (DUBEY et al., 1999). In China, although there are several serological surveys for $T$. gondii infection in horses and some Chinese reports were recently summarised (MIAO et al., 2013; YANG et al., 2013), information on horses remains limited in northwestern China. To the best of our knowledge, there has been only one survey performed in Xinjiang, northwestern China, and it took place more than 10 years ago. In that survey, $T$. gondii antibodies were assayed by IHA, and no positive sample was observed in the 60 serum samples. The aim of the present survey was to examine the prevalence of antibodies against $T$. gondii in horses in Xinjiang, northwestern China, providing fundamental data for understanding the main transmission routes between animals and humans, as well as preventing and controlling this disease.

\section{Materials and Methods}

\section{Region and samples}

Xinjiang Uygur Autonomous Region is located in northwest China, covering an area of approximately $1,660,000 \mathrm{Km}^{2}$ and occupying approximately one-sixth of the area of China. The climate in this region is typically temperate and monsoonal continental with an annual precipitation of $150 \mathrm{~mm}$, temperature differences between day and night, and abundant sunshine (yearly sunlight exposure of 2500-35000 h). A total of 637 blood samples were collected from August to December in 2011 in Changji Hui Autonomous Prefecture, Xinjiang. In total, 84, 103, 80, 91, 94, 93 and 92 blood samples were obtained from Miao'ergou, Jimusa'er, Hutubi, Qitai, Manasi, Fukang, and Mulei Kazakh Autonomous County, respectively. Information regarding the age, gender and geographic origin of each horse were obtained. The ages of the horses were classified into four groups: foal ( $0<$ age $\leq 1,129$ samples), adolescent ( $1<$ age $\leq 5,118$ samples), middle-aged ( 5 <age $\leq 10,326$ samples) and elderly (age $>10,64$ samples). In total, 248 of the sampled animals were male, and 389 were female. Blood samples were centrifuged at $3000 \times \mathrm{g}$ for $5 \mathrm{~min}$. The separated serum samples were stored at $-20^{\circ} \mathrm{C}$ until use.

\section{Serological assay}

T. gondii antibodies were detected in serum samples by the modified agglutination test (MAT) as described previously (DUBEY \& DESMONTS, 1987). In brief, serum samples were added to 96-well " $U$ " bottomed polystyrene plates and then diluted twofold from 1:25 to 1:3200. Positive and negative control serums were included in each test, and controversial serums were re-tested. Horse sera with MAT titres of 1:25 or higher were considered positive for T. gondii antibodies based on previous studies (YANG et al., 2013; GARCÍA-BOCANEGRA et al., 2012; ALVARADO-ESQUIVEL et al., 2012).

\section{Statistical analysis}

Statistical analysis was performed using SAS [Version 8.0] and SPSS [Release 18.0 standard version]. The risk factors (age, gender and region) were analysed using multivariable logistic regression models in SPSS. Differences in the seroprevalence of T. gondii-infected male and female horses, among various age groups and regions, were analysed using a Chi square test with SPSS. A value of $P<0.05$ was considered statistically significant.

\section{Results}

A total of 637 horses from seven regions in Changji Hui Autonomous Prefecture, Xinjiang, were assayed by MAT for T. gondii antibodies. In total, 200 of 637 horses (31.4\%, 95\% CI 27.79-35.00) were seropositive for $T$. gondii with titres of 1:25 in 86 individuals, $1: 50$ in 55, 1:100 in $37,1: 200$ in $11,1: 400$ in 2, 1:800 in 3, and 1:1600 or higher in 6. The seroprevalence of $T$. gondii infection from seven regions ranged from $27.7 \%$ in Manasi to $37.5 \%$ in Hutubi. Infected horses were observed in all age groups, ranging from 26.6-35.7\%. Prevalence in female was $33.1 \%$ and in male horses $28.9 \%$ (Table 1 ).

\section{Discussion}

Age, gender and region were not significant in the logistic regression analysis $(\mathrm{P}>0.05)$, suggesting that age, gender and region were not crucial factors for $T$. gondii infection, a finding that was consistent with the results of previous studies (MIAO et al., 2013; YANG et al., 2013). The present study showed that all the regions had $T$. gondii positive horses, and there were no significant 
differences among the various regions in Changji Hui Autonomous Prefecture, Xinjiang $(\mathrm{P}>0.05)$. Seroprevalence to $T$. gondii in male horses $(28.6 \%, 95 \%$ CI 23.00-34.26) was lower than that in female horses $(33.1 \%, 95 \%$ CI 28.48-37.84). Difference was not significant $(\mathrm{p}>0.05)$. Similar findings were reportedin a previous study in Portugal (LOPES et al., 2013). Regarding age group, also no association was observed, however the highest prevalence $(35.7 \%$, 95\% CI 27.39-43.93) was observed in foals. A relatively lower prevalence was observed in older horses $(26.6 \%$, 95\% CI 15.74-37.38), which was contrary to the result reported in a previous survey in Tunisia (BOUGHATTAS et al., 2011).

Globally, a few surveys have previously reported the prevalence of T. gondii in horses (Table 2). In the present study, the overall average $T$. gondii seroprevalence in Changji Hui Autonomous Prefecture, Xinjiang was 31.4\%, which was similar to that observed in Yunnan Province $(30.5 \%)$ but higher than that in Liaoning province (25.0\%) (MIAO et al., 2013; YANG et al., 2013). Horses are considered clinically resistant to $T$. gondii, and the prevalence of $T$. gondii in horses was generally lower in most countries, such as $1 \%$ in Sweden (JAKUBEK et al., 2006); $1.8 \%$ in Greece
(KOUAM et al., 2010); 2.6\% in Jeju Island, South Korea (GUPTA et al., 2002); 6.1\% in Mexico (ALVARADO-ESQUIVEL et al., 2012); 6.9\% in North America (DUBEY et al., 1999); $7.2 \%$ in Turkey (KARATEPE et al., 2010); 10.8\% in southern Spain (GARCÍA-BOCANEGRA et al., 2012); and 13.3\% in Portugal (LOPES et al., 2013). However, higher prevalences included 31.6\% in Saudi Arabia (ALANAZI \& ALYOUSIF, 2011); 34\% in Costa Rica (DANGOUDOUBIYAM et al., 2011); $52.6 \%$ in Egypt (SHAAPAN \& GHAZY, 2007); and 71.2\% in Iran (HAJIALILO et al., 2010). These differences in seroprevalence are most likely caused by differences in ecological and geographical factors, serological test methods, living styles and the number of infected cats.

The results of the present study indicated a high prevalence of T. gondii in horses in Changji Hui Autonomous Prefecture, Xinjiang, which may represent a potential source of human infection with T. gondii. Therefore, a more targeted approach to address this problem should be executed to control and prevent T. gondii infection in horses from Xinjiang, northwestern China.

Table 1. Seroprevalence of Toxoplasma gondii infection in horses in Changji, Xinjiang Uygur Autonomous Region, northwestern China.

\begin{tabular}{cccccccc}
\hline Factor & Category & No. tested & No. positive & Prevalence (\%) & 95\% CI & OR (95\%) & p-value \\
\hline \multirow{2}{*}{ Gender } & Male & 248 & 71 & 28.6 & $23.1-34.7$ & Reference & $P=0.255$ \\
& Female & 389 & 129 & 33.2 & $28.5-38.1$ & $1.24(0.87-1.75)$ \\
Age & $0<$ age $\leq 1$ & 129 & 46 & 35.7 & $27.4-44.6$ & Reference & $P=0.587$ \\
& $0<$ age $\leq 5$ & 118 & 35 & 29.7 & $21.6-38.8$ & $0.76(0.45-1.30)$ \\
& $5<$ age $\leq 10$ & 326 & 102 & 31.3 & $26.4-36.7$ & $0.82(0.53-1.26)$ \\
& age>10 & 64 & 17 & 26.6 & $16.3-39.1$ & $0.65(0.34-1.26)$ \\
& Fukang & 93 & 28 & 30.1 & $21.0-40.5$ & Reference & $P=0.829$ \\
& Jimusa'er & 103 & 34 & 33.0 & $24.1-43.0$ & $1.14(0.63-2.10)$ \\
& Hutubi & 80 & 30 & 37.5 & $26.9-49.0$ & $1.39(0.74-2.62)$ \\
& Qitai & 91 & 27 & 29.7 & $20.5-40.2$ & $0.98(0.52-1.84)$ \\
& Mulei & 92 & 31 & 33.7 & $24.2-44.3$ & $1.17(0.63-2.20)$ \\
& Manasi & 94 & 26 & 27.7 & $18.9-37.8$ & $0.89(0.47-1.67)$ \\
& Miao'ergou & 84 & 24 & 28.6 & $19.2-39.5$ & $0.93(0.49-1.78)$ \\
\hline
\end{tabular}

No. represents Number; CI is confidence intervals; OR is Odds-ratios.

Table 2. The seroprevalence of Toxoplasma gondii infection in horses globally.

\begin{tabular}{cccccc}
\hline Region & Sample size & Prevalence (\%) & Serological test & Cut off & Reference \\
\hline Ankara Province, Turkey & 100 & 28.0 & SFDT & $1: 16$ & (GÜÇLÜ et al., 2007) \\
Curitiba, Paraná, Brazil & 100 & 17.0 & IFAT & $1: 64$ & (FINGER et al., 2013) \\
Costa Rica & 315 & 34.0 & MAT & $1: 25$ & (DANGOUDOUBIYAM et al., 2011) \\
Czech Republic & 522 & 22.6 & LAT & $/$ & (BÁRTOVÁ et al., 2010) \\
Durango State, Mexico & 495 & 6.1 & MAT & $1: 25$ & (ALVARADO-ESQUIVEL et al., 2012) \\
Fernando de Noronha, & 16 & 43.7 & MAT & $1: 25$ & (COSTA et al., 2012) \\
Brazil & & & & (SHAAPAN \& GHAZY, 2007) \\
Giza-Zoo Egypt & 150 & 52.6 & Bioassays in mice & $/$ & (HARIDY et al., 2009) \\
Greater Cairo, Egypt & 100 & 25.0 & ELISA & $/$ & (KOUAM et al., 2010) \\
Greece & 753 & 1.8 & ELISA & (GUPTA et al., 2002)
\end{tabular}

MAT: modified agglutination test; IHA: indirect hemagglutination test; ELISA: enzyme-linked immunoabsorbent assay; SFDT: Sabin Feldman dye test; LAT: latex agglutination test; DAT: direct agglutination test; IFAT: indirect fluorescence antibody test. 
Table 2. Continued...

\begin{tabular}{|c|c|c|c|c|c|}
\hline Region & Sample size & Prevalence (\%) & Serological test & Cut off & Reference \\
\hline Liaoning Province, China & 711 & 25.0 & MAT & $1: 25$ & (YANG et al., 2013) \\
\hline New Caledonia & 25 & 16.0 & ELISA & / & (ROQUEPLO et al., 2011) \\
\hline Niğde Province, Turkey & 125 & 7.2 & SFDT & $1: 16$ & (KARATEPE et al., 2010) \\
\hline North America & 1788 & 6.9 & MAT & $1: 20$ & (DUBEY et al., 1999) \\
\hline Portugal & 173 & 13.3 & MAT & $1: 20$ & (LOPES et al., 2013) \\
\hline Qazvin, Iran & 52 & 71.2 & MAT & $1: 20$ & (HAJIALILO et al., 2010) \\
\hline $\begin{array}{c}\text { Riyadh Province, Saudi } \\
\text { Arabia }\end{array}$ & 266 & 31.6 & SFDT & $1: 16$ & (ALANAZI \& ALYOUSIF, 2011) \\
\hline Southern Spain & 454 & 10.8 & MAT & $1: 25$ & (GARCÍA-BOCANEGRA et al., 2012) \\
\hline Swedish & 414 & 1.0 & DAT & $1: 40$ & (JAKUBEK et al., 2006) \\
\hline Tunisia & 158 & 17.7 & MAT & $1: 20$ & (BOUGHATTAS et al., 2011) \\
\hline Urmia, Northwest Iran & 26 & 11.5 & MAT & $1: 20$ & (RAEGHI et al., 2011) \\
\hline Yunnan Province, China & 266 & 30.5 & IHA & $1: 64$ & (MIAO et al., 2013) \\
\hline
\end{tabular}

MAT: modified agglutination test; IHA: indirect hemagglutination test; ELISA: enzyme-linked immunoabsorbent assay; SFDT: Sabin Feldman dye test; LAT: latex agglutination test; DAT: direct agglutination test; IFAT: indirect fluorescence antibody test.

\section{Acknowledgements}

This study was funded by the National Natural Science Foundation of China (Grant No. 31302085) and the Science Fund for Creative Research Groups of Gansu Province (Grant No. 1210RJIA006).

\section{References}

Alanazi AD, Alyousif MS. Prevalence of antibodies to Toxoplasma gondii in horses in Riyadh Province, Saudi Arabia. J Parasitol 2011; 97(5): 943945. http://dx.doi.org/10.1645/GE-2677.1. PMid:21506811.

Alvarado-Esquivel C, Rodríguez-Peña S, Villena I, Dubey JP. Seroprevalence of Toxoplasma gondii infection in domestic horses in Durango State, Mexico. J Parasitol 2012; 98(5): 944-945. http://dx.doi.org/10.1645/ GE-3174.1. PMid:22559329.

Barros LD, Taroda A, Zulpo DL, Cunha IAL, Sammi AS, Cardim ST, et al. Genetic characterization of Toxoplasma gondii isolates from eared doves (Zenaida auriculata) in Brazil. Rev Bras Parasitol Vet 2014; 23(4): 443448. http://dx.doi.org/10.1590/S1984-29612014073. PMid:25517521.

Bártová E, Sedlák K, Syrová M, Literák I. Neospora spp. and Toxoplasma gondii antibodies in horses in the Czech Republic. Parasitol Res 2010; 107(4): 783-785. http://dx.doi.org/10.1007/s00436-010-1929-4. PMid:20532561.

Belanger F, Derouin F, Grangeot-Keros L, Meyer L, HEMOCO, SEROCO Study Groups. Incidence and risk factors of toxoplasmosis in a cohort of human immunodeficiency virus-infected patients: 1988-1995. Clin Infect Dis 1999; 28(3): 575-581. http://dx.doi.org/10.1086/515147. PMid:10194081.

Boughattas S, Bergaoui R, Essid R, Aoun K, Bouratbine A. Seroprevalence of Toxoplasma gondii infection among horses in Tunisia. Parasit Vectors 2011; 4(1): 218. http://dx.doi.org/10.1186/1756-3305-4-218. PMid:22107730.

Cerro L, Rubio A, Pinedo R, Mendes-de-Almeida F, Brener B, Labarthe N. Seroprevalence of Toxoplasma gondii in cats (Felis catus, Linnaeus 1758) living in Lima, Peru. Rev Bras Parasitol Vet 2014; 23(1): 90-93. http:// dx.doi.org/10.1590/S1984-29612014013. PMid:24728367.
Costa DG, Marvulo MF, Silva JS, Santana SC, Magalhães FJ, Lima CD Fo, et al. Seroprevalence of Toxoplasma gondii in domestic and wild animals from the Fernando de Noronha, Brazil. J Parasitol 2012; 98(3): 679-680. http://dx.doi.org/10.1645/GE-2910.1. PMid:22150091.

Dangoudoubiyam S, Oliveira JB, Víquez C, Gómez-García A, González O, Romero JJ, et al. Detection of antibodies against Sarcocystis neurona, Neospora spp., and Toxoplasma gondii in horses from Costa Rica. J Parasitol 2011; 97(3): 522-524. http://dx.doi.org/10.1645/GE-2722.1. PMid:21506839.

Dubey JP, Desmonts G. Serological responses of equids fed Toxoplasma gondii oocysts. Equine Vet J 1987; 19(4): 337-339. http://dx.doi. org/10.1111/j.2042-3306.1987.tb01426.x. PMid:3622463.

Dubey JP, Thulliez P, Romand S, Kwok OCH, Shen SK, Gamble HR. Serologic prevalence of Toxoplasma gondii in horses slaughtered for food in North America. Vet Parasitol 1999; 86(4): 235-238. http://dx.doi. org/10.1016/S0304-4017(99)00148-X. PMid:10536980.

Dubey JP. Toxoplasmosis of animals and humans. 2nd ed. Boca Raton, FL: CRC Press; 2010.

Elmore SA, Jones JL, Conrad PA, Patton S, Lindsay DS, Dubey JP. Toxoplasma gondii: epidemiology, feline clinical aspects, and prevention. Trends Parasitol 2010; 26(4): 190-196. http://dx.doi.org/10.1016/j. pt.2010.01.009. PMid:20202907.

Finger MA, Villalobos EMC, Lara MC, Cunha EMS, Barros IR Fo, Deconto I, et al. Detection of anti-Toxoplasma gondii antibodies in carthorses in the metropolitan region of Curitiba, Paraná, Brazil. Rev Bras Parasitol Vet 2013; 22(1): 179-181. http://dx.doi.org/10.1590/ S1984-29612013005000001. PMid:23459849.

García-Bocanegra I, Cabezón O, Arenas-Montes A, Carbonero A, Dubey JP, Perea A, et al. Seroprevalence of Toxoplasma gondii in equids from Southern Spain. Parasitol Int 2012; 61(3): 421-424. http://dx.doi. org/10.1016/j.parint.2012.02.003. PMid:22366344.

Güçlü Z, Karaer Z, Babür C, Kiliç S. Investigation of Toxoplasma gondii antibodies in sport horses bred in Ankara province. Turkiye Parazitol Derg 2007; 31(4): 264-267. PMid:18224613.

Gupta GD, Lakritz J, Kim JH, Kim DY, Kim JK, Marsh AE. Seroprevalence of Neospora, Toxoplasma gondii and Sarcocystis neurona antibodies in 
horses from Jeju island, South Korea. Vet Parasitol 2002; 106(3): 193-201. http://dx.doi.org/10.1016/S0304-4017(02)00064-X. PMid:12062508.

Hajialilo E, Ziaali N, Fasihi Harandi M, Saraei M, Hajialilo M. Prevalence of anti-Toxoplasma gondii antibodies in sport horses from Qazvin, Iran. Trop Anim Health Prod 2010; 42(7): 1321-1322. http://dx.doi.org/10.1007/ s11250-010-9576-4. PMid:20383793.

Haridy FM, Shoukry NM, Hassan AA, Morsy TA. ELISA-seroprevalence of Toxoplasma gondii in draught horses in Greater Cairo, Egypt. J Egypt Soc Parasitol 2009; 39(3): 821-826. PMid:20120748.

Jakubek EB, Lundén A, Uggla A. Seroprevalences of Toxoplasma gondii and Neospora sp. infections in Swedish horses. Vet Parasitol 2006; 138(3-4): 194-199. http://dx.doi.org/10.1016/j.vetpar.2006.02.002. PMid:16517077.

Karatepe B, Babür C, Karatepe M, Kiliç S. Seroprevalence of toxoplasmosis in horses in Niğde Province of Turkey. Trop Anim Health Prod 2010; 42(3): 385-389. http://dx.doi.org/10.1007/s11250-009-9430-8. PMid:19701805.

Kijlstra A, Jongert E. Control of the risk of human toxoplasmosis transmitted by meat. Int J Parasitol 2008; 38(12): 1359-1370. http:// dx.doi.org/10.1016/j.ijpara.2008.06.002. PMid:18694755.

Kouam MK, Diakou A, Kanzoura V, Papadopoulos E, Gajadhar AA, Theodoropoulos G. A seroepidemiological study of exposure to Toxoplasma, Leishmania, Echinococcus and Trichinella in equids in Greece and analysis of risk factors. Vet Parasitol 2010; 170(1-2): 170-175. http://dx.doi.org/1 0.1016/ j.vetpar. PMID: 20197215.

Lopes AP, Sousa S, Dubey JP, Ribeiro AJ, Silvestre R, Cotovio M, et al. Prevalence of antibodies to Leishmania infantum and Toxoplasma gondii in horses from the north of Portugal. Parasit Vectors 2013; 6(1): 178 http://dx.doi.org/10.1186/1756-3305-6-178. PMid:23773870.

Miao Q, Wang X, She LN, Fan YT, Yuan FZ, Yang JF, et al. Seroprevalence of Toxoplasma gondii in horses and donkeys in Yunnan Province, Southwestern China. Parasit Vectors 2013; 6(1): 168. http://dx.doi. org/10.1186/1756-3305-6-168. PMid:23742078.
Montoya JG, Liesenfeld O. Toxoplasmosis. Lancet 2004; 363(9425): 1965-1976. http://dx.doi.org/10.1016/S0140-6736(04)16412-X. PMid:15194258.

Pomares C, Ajzenberg D, Bornard L, Bernardin G, Hasseine L, Dardé $\mathrm{ML}$, et al. Toxoplasmosis and horse meat, France. Emerg Infect Dis 2011; 17(7): 1327-1328. http://dx.doi.org/10.3201/eid1707.101642. PMid:21762609.

Raeghi S, Akaberi A, Sedeghi S. Seroprevalence of Toxoplasma gondii in sheep, cattle and horses in Urmia North-West of Iran. Iran J Parasitol 2011; 6(4): 90-94. PMid:22347318.

Roqueplo C, Halos L, Cabre O, Davoust B. Toxoplasma gondii in wild and domestic animals from New Caledonia. Parasite 2011; 18(4): 345 348. http://dx.doi.org/10.1051/parasite/2011184345. PMid:22091467.

Shaapan RM, Ghazy AA. Isolation of Toxoplasma gondii from horse meat in Egypt. PakJ Biol Sci 2007; 10(1): 174-177. http://dx.doi.org/10.3923/ pjbs.2007.174.177. PMid:19070010.

Sousa RÁ, Lemos JF, Farias LA, Lopes CD, Santos KR. Seroprevalence and risk factors for Toxoplasma gondii infection in pigs in southern Piauí. Rev Bras Parasitol Vet 2014; 23(1): 98-100. http://dx.doi.org/10.1590/ S1984-29612014015. PMid:24728369.

Tenter AM, Heckeroth AR, Weiss LM. Toxoplasma gondii: from animals to humans. Int J Parasitol 2000; 30(12-13): 1217-1258. http://dx.doi. org/10.1016/S0020-7519(00)00124-7. PMid:11113252.

Yang N, Mu MY, Yuan GM, Zhang GX, Li HK, He JB. Seroprevalence of Toxoplasma gondii in slaughtered horses and donkeys in Liaoning province, northeastern China. Parasit Vectors 2013; 6(1): 140. http:// dx.doi.org/10.1186/1756-3305-6-140. PMid:23680297.

Zhou P, Chen Z, Li HL, Zheng H, He S, Lin RQ, et al. Toxoplasma gondii infection in humans in China. Parasit Vectors 2011; 4(1): 165. http:// dx.doi.org/10.1186/1756-3305-4-165. PMid:21864327. 